YAK 347.12

DOI https://doi.org/10.32837/chc.v0i42.434

Блохін Максим Юрійович,

аспірант кафедри цивільного права

Національного університету "ОАеська юридична академія"

ORCID ID: https://orcid.org/0000-0002-3922-5923

\title{
GENERAL DATA PROTECTION REGULATION (GDPR) ЯК ПОТЕНЦІЙНЕ ДЖЕРЕЛО ВДОСКОНАЛЕННЯ ВІТЧИЗНЯНОГО ЗАКОНОДАВСТВА У СФЕРІ ЗАХИСТУ ПЕРСОНАЛЬНИХ ДАНИХ
}

Постановка проблеми. Сучасне суспільство розвивається за графіком геометричної прогресії. Аонедавна технології сприймалися та використовувалися лише як своєріАний "полегшувач" життя, аАже вони Аопомагали АюАям вирішувати Аоволі повсякАенні побутові й виробничі проблеми, мінімізуючи рівень витрат АюАських сил та енергії, максимально відсторонюючи мюдину віА технічної й механічної роботи.

Але XXI століття трансформувало світ настільки, що уявити його без технологій неможливо. Технології стали невіА'ємною частиною сучасного життя. На особливу увагу заслуговують ті технології, що наАають індивіАам Аоступ Ао різного роду інформації, яка завАяки розвитку й розповсюАженню мережі Інтернет досягла майже незліченного об'єму. Тому в рамках тотальної інформатизації повсякАенного життя сучасне суспільство почало плавно (приблизно із зародженням інформаційних технологій у 60-х роках XX століття) переходити Ао нового етапу свого розвитку, який сучасні вчені іАентифікують як «інформаційне суспільство". У 1993 році сутність інформаційного суспільства розкрита Комісією ЄС: «нформаційне суспільство - це суспільство, у якому Аіяльність Аюдей зАійснюється на основі використання послуг, що надаються за Аопомогою інформаційних технологій і технологій зв'язку".

Варто зазначити, що далеко не вся інформація, яка знаходиться в мережі Інтернет, має бути загальнодоступною, аАже користувачі інформаційних технологій, які хоча б раз піА'єАнуються Ао "всесвітньої павутини", віАразу ж залишають там свій “інформаційний сліА" - персональні Аані, що являють собою масив унікальної індивіАуальної інформації про особу-користувача. Загальнодоступність такої інформації може негативно впли- нути на приватність цієї особи або навіть завдати їй великої моральної та матеріальної шкоди.

Вітчизняне законодавство, а саме Закон України "Про захист персональних даних", регу^ює правові відносини, пов'язані із захистом та обробкою персональних даних, і спрямований на захист основоположних прав і свобод людини та громаАянина, зокрема права на невтручання в особисте життя, у зв'язку з обробкою персональних даних. Він визначає персональні дані як відомості чи сукупність відомостей про фізичну особу, яка іАентифікована або може бути конкретно ідентифікована. А^е, як показує практика, цей Закон значно поступається закордонним аналогам, таким як європейський GDPR (General Data Protection Regulation), бразильський LGPD (Lei Geral de Proteção de Dados) та інші нормативні акти у сфері регулювання захисту персональних Ааних, особливо в питаннях щодо віАсліАковування надання згоди на обробку персональних Ааних, забезпечення захисту персональних даних і встановлення повноважень різних суб'єктів щодо збирання й обробки персональних Ааних.

На Аодаткову увагу, на нашу думку, заслуговує саме європейський варіант урегулювання сфери захисту персональних Ааних, а саме GDPR.

Загальний регламент про захист Ааних (англ. General Data Protection Regulation, GDPR; Regulation (EU) 2016/679) - регламент у межах законодавства Європейського Союзу щодо захисту персональних даних усіх осіб у межах Європейського Союзу та Європейської економічної зони. Він також стосується експорту персональних Ааних за межі ЄC і ЄE3. GDPR покликаний насампереА надати громадянам і резидентам $€ C$ контроль за їхніми персональними Ааними та спростити регуляторне середовище Аля міжна- 
родного бізнесу шляхом уніфікації регулювання в межах ЄC [1].

Стан АосліАження теми. Оскільки GDPR $€$ Аоволі новим нормативним актом (прийнятий 27 квітня 2016 року та набув чинності 25 травня 2018 року), а стан Аослідження сфери ІТ-права й інституту захисту персональних Ааних знахоАиться на початковому етапі, у вітчизняному науковому товаристві практично відсутні роботи, у яких приділяють увагу саме темі захисту персональних Ааних за GDPR як оАного з основних актів у цій сфері.

Метою статті $€$ аналіз потенціалу цього нормативного акта та його окремих положень з метою ознайомлення й оцінки можливості його імплементації в сучасне українське законодавство.

ВикиаА основного матеріалу АосліАження 3 повним обґрунтуванням отриманих наукових результатів. Аля подальшого аналізу варто більше детально розібратися, що таке GDPR, його основні положення, сфера його дії та суб'єкти, які керуються ним у Аіяльності.

Загальний регламенту про захист Ааних (General Data Protection Regulation) (Аалі - Регмамент) установлює правила обробки персональних даних, зага^ьні для всіх країн-учасниць, і враховує всі зміни у сфері комп'ютерних технологій, що відбулися в останні роки, які суттєво вплинули на процес обробки даних. Його завдання полягає в приведенні чинних правил обробки персональних Ааних у віАповіАність Ао вимог нових техно^огій, вк^ючаючи Інтернет, хмарні обчислення й соціальні мережі [4].

Нові правила захисту Ааних поширюються не тільки в межах ЄС, а й Аля всіх компаній, які працюють у ЄС навіть без штаб-квартири компанії в ЄС та обробляють персональні дані громадян Європи. Обробка персональних даних відбувається в момент, коли вони продають товари чи послуги ^юдям у ЄС, або надають товари та послуги безкоштовно, або аналізують поведінку користувачів Інтернету. Окрім компаній, GDPR також поширюється на Аержавні аАміністрації, які пропонують усе більше цифрових послуг у контексті електронного уряду.

Передусім варто зазначити, що, за нормами Регламенту, споживачі завжди повністю поінформовані про те, що відбувається з їхніми Ааними, а також мають можливість заперечити проти обробки своїх Ааних. Європейський законодавець хоче проінформувати громадян про те, хто володіє їхніми Ааними та як вони можуть реалізувати свої права стосовно процесу збору й обробки цих Ааних. Аля компаній (юридичний осіб) також $€$ свої переваги: наприклаА, нові зобов'язання, передбачені Регламентом, щодо видалення персональних Ааних можуть Аопомоти компаніям більш "чисто" обробляти персональні Аані. Тому в разі Аотримання компанією правил повоАження з персональними Ааними це сприятиме піАвищенню її Аілової репутації та іміАжу в цілому, а це, у свою чергу, може дати їм перевагу на конкурентному ринку.

Наступним позитивним моментом хотілося би виділити чітке розмежування "ролей" у контексті збору, обробки та використання персональних Ааних. Так, статтею 4 Регламенту введені такі понятт:

- контролер даних (англ. data controller) фізична або юридична особа, Аержавний орган, установа або інший орган, який самостійно або спільно з іншими визначає цілі й засоби обробки персональних Ааних, наприклаА, соціальна мережа або служба таксі;

- обробник даних (англ. data processor) - це фізична або юридична особа, Аержавний орган, установа або інший орган, який обробляє персональні дані віА імені за дорученням контролера, наприклаА, постачальник хмарних послуг;

- суб'єкт даних (особа) (англ. data subject (person)) - фізична особа, Аані якої обробляються;

- спеціальні категорії персональних даних (англ. special categories of personal data) - Аані про расу, політичну Аумку, релігійні або філософські переконання, генетичні Аані, членство в профспілках, біометричні дані, що Аають змогу визначити конкретну мюдину, Аані про зАоров'я, сексуальну орієнтацію.

Чи не найбільшим позитивним нововведенням $€$ розширення й визначення найважливіших прав суб'єктів Ааних:

- право на прозору інформацію та спіккування щодо використання персональних Ааних;

- право знати, коли збираються й обробляються персональні дані;

- право перевіряти збережені дані;

- право на виправлення даних;

- право на видалення даних (право на забуття). Це право Аублюється 3 Аирективи 95/46/ЕС. Суб'єкти Ааних мають право на видамення будь-якої інформації про персональні дані особи (у тому числі будь-яка інформація з результатів пошуку, посилання, повідомлення тощо). Таке право суб'єктів персональних даних кореспонаується обов'язком контролера зАійснити 
видалення подібної інформації. Будь-яка компанія, що обробляє персональні Аані, зобов'язана видаляти такі дані за запитом суб'єкта таких Ааних, якщо це не суперечить інтересам суспільства або іншим фундаментальним правам ^юАини [3];

- право заборонити обробку/використання Ааних;

- право на переносимість даних. Це право полягає в тому, що компанії зобов'язані надавати на безоплатній основі електронну копію персональних Ааних іншій компанії на вимогу самого суб'єкта персональних даних. НаприклаА, суб'єкт Ааних користується сервісом "carsharing" Компанії № 1 і через Аеякий час суб'єкт Ааних виявив намір припинити користуватися послугами компанії № 1 і почав користуватися послугами "carsharing" Компанії № 2. У такому випаАку право на переносимість Аозволяє отримати персональні дані віА Компанії № 1 і передати їх іншому сервісу, наприклаА, Компанії № 2) [3];

- право на отримання даних у портативному форматі;

- право на заперечення (наприклаА, пізніше);

- право на той факт, що дані не обробляються автоматично без згоди, якщо це має юридичні наслідки (наприклаА, при оформленні страховки або заяві на кредитну картку);

- обмеження прав: коли існують "Вищі закони", вони обмежують права суб'єкта Ааних. (НаприклаА, строки зберігання рахунків-фактур і контрактів, національна безпека, розслідування поліції тощо.)

На особливу увагу заслуговує впровадження нормами GDPR інституту уповноваженого (офіцера) із захисту Ааних (англ. data protection office, або ж DPO). Усупереч поширеній Аумці, вирішальним Аля юриАичного зобов'язання щодо призначення співробітника із захисту даних $€$ не розмір компанії, а основна Аіяльність, пов'язана з обробкою Ааних, яка визначається як така, що $€$ важливою Аля Аосягнення цілей компанії. Якщо ці основні виАи Аіяльності полягають у широкомасштабній обробці конфіденційних персональних Ааних або у формі обробки Ааних, які $€$ особливо важливими Аля прав суб'єктів Ааних, компанія повинна призначити таку відповідальну особу. Також Регламентом передбачено, що державні органи завжАи повинні призначати DPO, за винятком судів (з осіб, які працюють у судах). Крім того, законодавча норма про призначення уповноваженого із захисту даних містить положення щодо гнучкості Аля Аержав-членів Європейського Союзу. Вони мають право вирішувати, чи має компанія призначати співробітника з питань захисту даних залежно від більш жорстких вимог, передбачених національним законодавством країни-члена (наприклаА, розділ 38 Фелерального закону про захист Ааних Німеччини). Також, відповідно до Регламенту й норм національного законодавства, група підприємств може призначити оАного уповноваженого із захисту Ааних, який охоплюватиме Аіяльність Аекількох компаній (суб'єктів) одночасно. Якщо група вирішує це зробити, то ця особа має перебувати у вільному Аоступі Аля всіх контролюючих органів, працівників і зовнішніх суб'єктів Ааних. Якщо жодних юридичних зобов'язань щодо захисту персональних даних не існує, компанії можуть добровільно призначити DPO Аля Аопомоги компанії або державного органу в Аотриманні вимог щодо захисту Ааних.

Стосовно оскарження власників персональних Ааних щодо порушення їхніх прав, то, відповідно Ао Регламенту, кожна країна-член ЄС має національний (уповноважений) орган управління захистом Ааних (англ. data protection authority, або ж DPA). DPA несуть відповідальність за встановлення віАповіАності й утілення в життя віАповіАних законів на національному рівні, але зобов'язані бути незалежними навіть віА контролю з боку власного національного уряду. Країни-члени Співтовариства можуть мати один або більше органів управління. Кожна організація може вибрати один DPA, який контролює віАповідність GDPR Аля організації в цілому. ЄАиний наглядовий орган має можливість контролювати обробку й захист Ааних, що забезпечуються в інших країнах-членах. Орган управління захистом Ааних допомагає приймати рішення в правових питаннях і може розслідувати Аіяльність компаній у разі порушень, припиняти роботу керуючих Ааними й обробників, які несуть юридичну відповідальність за порушення GDPR, і визначати штрафні санкції. Крім того, він вирішує, чи може організація передавати Аані за межі ЄC, якщо так, то які механізми захисту варто застосувати. У конкретній організації основною особою, що піАтримує зв'язок із DPA, буде керівник із захисту персональних Ааних [10].

Також постраждалі особи можуть подати скаргу Ао віАповідального наглядового органу в $€ C$ (DPA) у разі виявлення ними будь-яких порушень. Якщо DPA виявлять будь-які порушення захисту персональних даних, вони в майбутньому будуть зобов'язані повідомити про це наглядові Аержавні органи в строк протягом 72 годин. 
Таким чином, повноваження наглядових державних органів значно посилюються, а тому в майбутньому, швидше за все, ми будемо бачити все більше й більше правових конфліктів між великими Інтернет-компаніями, такими як Facebook чи Google, та органами державної влади, які Аіятимуть в інтересах своїх громадян.

Загальноєвропейським контролюючим органом є Європейська рада з захисту даних (European Data Protection Board). Також окремо на рівні Аержав-членів ЄС Аіють регулюючі органи, які $\epsilon$ національними регуляторами у сфері захисту персональних Ааних [3].

За особливо грубі порушення, перераховані в статті 83 (5) Регламенту, розмір штрафу може становити до 20 мільйонів євро або у випадку зобов'язання Ао 4\% їх загального задекларованого обороту за попередній фінансовий рік, залежно віА того яке значення буде вищим. Але навіть за менш серйозні порушення, зазначені в статті 83 (4) Регламенту, передбачено штрафи в розмірі до 10 мільйонів євро або в разі чинного зобов'язання до 2\% віА загального задекларованого обороту попереднього фінансового року, залежно віА того яке значення буде вищим.

Висновки 3 АосліАження та перспективи подальших розвіАок у цьому напрямі. ПіАсумовуючи, можна з упевненістю сказати, що GDPR
$€$ найбільш розвиненим і прогресивним нормативним актом, який стосується питань захисту персональних Ааних. Спектр правовіАносин, що регулюються цим нормативним актом, визначеність понять, екстериторіальність його дії та віАсутність проблем у практичному застосуванні явно виділяються його з-поміж усіх інших світових нормативних актів, особливо порівняно з вітчизняним законодавством.

Отже, видається, що положення GDPR обов'язково мають бути використані Аля вАосконалення чинного законодавства, а саме виправлення його недоліків та усунення колізій, створення всіх необхідних умов Аля його ефективного застосування на практиці Аля безперешкодного захисту прав та інтересів громадян щодо захисту персональних Ааних. Але імплементація цього нормативного акта може потребувати багато зусиль, аАже при його прийнятті законотворці опиралися на вже сформовану законодавчу базу країн ЄС і різні напрацювання у сфері інформаційної безпеки. Звісно, такі зміни будуть уноситися саме до вже чинного Закону України "Про захист персональних даних", який не є настільки розвиненим, і все ж таки при раціональному опрацюванні вищезазначених позитивних сторін українське законодавство у сфері кібербезпеки може зазнати значних і вагомих поліпшень.

\section{NITEPATYPA:}

1. Drexl J. Legal Challenges of the Changing Role of Personal and Non-Personal Data in the Data Economy. Max Planck Institute for Innovation \& Competition Research Paper. 2018. № 18-23.

2. Presidency of the Council: «Compromise text. Several partial general approaches have been instrumental in converging views in Council on the proposal for a General Data Protection Regulation in its entirety. The text on the Regulation which the Presidency submits for approval as a General Approach appears in annex», 201 pages, 11 June 2015.

3. Гвоздій B.A. General Data Protection Regulation. URL: http://unba.org.ua/publications/3320-general-data-protection-regulation. html.

4. Грибанов А. А. Общий регламент о защите персональных данных (General Data Protection Regulation): идеи для совершенствования российского законодательства. Закон. 2018. № 3. C. 149-162. URL: https://urfac.ru/?p=437.

5. Згода суб'єкта персональних даних. Термінологічний словник з питань запобігання та протидії легалізації (відмиванню) доходів, одержаних злочинним шляхом, фінансуванню тероризму, фінансуванню розповсюдження зброї масового знищення mа корупиії / А.Г. Чубенко, М.В. Лошицький, Д.М. Павлов, С.С. Бичкова, О.С. Юнін. Київ : Ваіте, 2018. С. 280.

6. Крылова М.С. Принципы обработки персональных данных в праве Европейского Союза. Актуальные проблемы российского права. 2017. № 10. С. 175-181.

7. Про захист персональних даних : Закон України № 2297-VI (2010). URL: https://zakon.rada.gov.ua/laws/show/2297-17.

8. Про інформацію : Закон України № 2657-XII (1992). URL: https://zakon.rada.gov.ua/laws/show/2657-12.

9. Регламент (СС) 2016/679 Європейського парламенту та Ради від 27 квітня 2016 року про захист фізичних осіб у зв'язку з опрацюванням персональних даних і про вільний рух таких даних та про скасування Директиви 95/46/ЄС. URL: https://www.kmu.gov.ua/storage/app/media/uploaded-files/es 2016679.pdf.

10. Роджер А. Граймз. Как защитить персональные данные в соответствии с GDPR. CSO. 2017.14 августа. URL: https://www.osp.ru/cio/2017/07/13052957.

11. Сопілко І.М. Становлення інформаційного суспільства та інформаційні загрози в мережі Інтернет. Юридичний вісник. 2017. № 3 (44).

12. Гуз А.М., Касперський І.П., Ткачук Т.Ю. Організація захисту інформації з обмеженим доступом : навчальний посібник. Київ : НА СБУ, 2018. С. 33-58.

13. Ткачук Т.Ю., Довгань О.Д. Правове забезпечення інформаційної безпеки держави як підгалузь інформаційного права: теоретичний дискурс. Інформація і право. 2018. № 2 (25). С. 73-85. 


\section{Блохін Максим Юрійович \\ GENERAL DATA PROTECTION REGULATION (GDPR) ЯK ПОТЕНЦІЙHE АЖEPE^О ВАОСКОНАЛЕНHЯ ВІТЧИЗНЯНОГО ЗАКОНОААВСТВА У СФЕРІ ЗАХИСТУ ПЕРСОНААЬНИХ ААНИХ}

Стаття присвячена питанням захисту персональних даних у мережі Інтернет нормативним актом Європейського Союзу - GDPR (General Data Protection Regulation) - і його позитивним сторонам, які можна імплементувати у вітчизняне законодавство з метою його вдосконалення. Так як цей регуляторний акт уже широко використовується в Європі певний період часу, то відслідкувати рівень його Аієвості можна на реальній практиці застосування GDPR країнами-членами Європейського Союзу. Розглянуто передумови виникнення цього закону та його прийняття Європейським Союзом, визначено термін “інформаційне суспільства" та його значимість у виникненні цих передумов. Повністю розглянуто сферу Аії цього акта та його особливості врегулювання питань захисту персональних даних. Проаналізовані дефініції нових понять та інститутів, запропонованих цим нормативним актом, такі як контролер даних, обробник даних, суб'єкт Ааних (особа), спеціальні категорії персональних Ааних. Окреслено рамки Аії цього нормативного акта (суб'єктні, темпоральні, територіальні тощо). Проведено АосліАження особливості структури цього акта (у вигляАі, актуальному на момент написання статті). Охарактеризовано ексклюзивні види прав, які введені цим нормативним актом, такі як право на видалення даних (право на забуття), право на переносимість даних, та інші види прав, передбачені GDPR. Визначено ліміти відповідальності суб'єктів і штрафні санкції, які застосовуються в разі вчинення суб'єктами порушень різних рівнів у сфері захисту персональних Ааних. Описано роль уповноваженого (офіцера) із захисту Ааних (або ж DPO). Проаналізовано окремі його положення, які заслуговують на особливу увагу. Визначено характерні риси цього акта, які відрізняють його віА інших світових аналогів. Описано процедуру звернення постраждалих осіб з метою захисту своїх порушених прав та інтересів у сфері захисту персональних Ааних. Охарактеризовано його значимість Аля розвитку світового регулювання інституту захисту персональних Ааних і всіх суміжних правовідносин.

Киючові слова: IT-право, GDPR, захист персональних даних, використання персональних даних, інформаційна безпека, кібербезпека, інформаційне законодавство.

\section{Blokhin Maksym \\ GENERAL DATA PROTECTION REGULATION (GDPR) AS POTENTIAL SOURCE OF IMPROVEMENT OF THE DOMESTIC LEGISLATION IN THE SPHERE OF PERSONAL DATA PROTECTION}

The article is devoted to the protection of personal data in the Internet by the normative act of the European Union - GDPR (General Data Protection Regulation) and its positive aspects, which can be implemented in domestic legislation in order to improve it. Since this regulatory act has been widely used in Europe for some time, it is possible to trace the level of its effectiveness in the actual practice of application of the GDPR by the member states of the European Union. The preconditions for the emergence of this law and its adoption by the European Union are considered, the term "information society" and its significance in the emergence of these preconditions are defined. The scope of this act and its features of regulation of personal data protection are fully considered. The definitions of new concepts and institutions proposed by this normative act, such as data controller, data processor, data subject (person), special categories of personal data are analyzed. The scope of this normative act (subjective, temporal, territorial and others) is outlined. A study of the peculiarities of the structure of this act (in the form relevant at the time of writing). The exclusive types of rights introduced by this normative act, such as the right to delete data (right to be forgotten), the right to data portability and other types of rights provided by the GDPR are described. The limits of responsibility of subjects and penalties which are applied in case of commission by subjects of infringements of various levels in the field of protection of personal data are defined. The role of the Data Protection Officer (or DPO) is described. Some of its provisions that deserve special attention are analyzed. The characteristic features of this act that distinguish it from other world analogues are determined. The procedure for appealing to victims in order to protect their violated rights and interests in the field of personal data protection is described. The significance for the development of global regulation of the institute of personal data protection and all related legal relations is described.

Key words: IT law, GDPR, personal data protection, use of personal data, information security, cybersecurity, information legislation. 